\title{
\$sciendo
}

DOI 10.2478/afepuc-2021-0006

(C) 2022 Author(s). This is an open access article licensed under the Creative Commons

Attribution-NonCommercial-NoDerivatives 4.0 International

(https://creativecommons.org/licenses/by-nc-nd/4.0/)

\section{PHYSICAL AND MOVEMENT SKILL LEVEL OF PUPILS FROM THE FIRST GRADE OF PRIMARY SCHOOL IN SVIT IN COMPARISON WITH NATIONAL RESEARCH OF PRIMARY SCHOOLS Ladislava Doležajová ${ }^{1}$, Lenka Poništová2 ${ }^{2}$ Olympia Mókusová ${ }^{1}$}

${ }^{1}$ Comenius University in Bratislava, Faculty of Physical Education and Sport, Slovakia

${ }^{2}$ Teacher et a primary school in Poprad, Slovakia

\begin{abstract}
Summary: The aim of the work was to compare the level of somatic and selected motor abilities of pupils of the 1st year in Svit with a national research of primary schools. The goal was to choose boys for athletic training based on individual and overall physical performance. The parameters showing the bodily development of the probands were body height, body weight and BMI index. To determine the all-round readiness of students, we used a test set consisting of the following tests: maximum forward bend, endurance in pull-ups, long jump from standing position, shuttle run $4 \times 10 \mathrm{~m}$ and endurance Beep test. We processed empirical data using statistical-mathematical characteristics. We used the Shapiro-Wilk test to calculate the normality of the data and then calculated the statistical significance of the mean values using the Parametric Unpaired T-test. We recorded significant differences at the 1\% and 5\% level of statistical significance when comparing the results of our groups with the national ones in individual motor tests: maximum forward bend, long jump from a place, shuttle run 4 x $10 \mathrm{~m}$ and endurance Beep test. Differences in somatic indicators and performance between Svit students were confirmed without statistical significance. In the end, we evaluated the level of performance of pupils according to the standards of the population on the basis of their achieved results. We recommended children who achieved the highest points of overall readiness for athletic preparations, as well as those who showed an above-average level of performance in individual tests.
\end{abstract}

Key words: national testing, physical performance, primary schools, boys

\section{Introduction}


Since the $1^{\text {st }}$ of September 2018, a nationwide testing of the movement preconditions of pupils in the first and third grades of primary schools was organized every year with the intention of identifying sports talent (Šimonek \& Židek 2019).

The authors Šimonek \& Židek (2019) and Ružbarský (2018) agree on the reason for choosing children aged from $6-7$. The main reason is the fact that few of these children participate in some controlled sports training or devote themselves to it for a short time, thus suppressing the influence of the social environment on the development of physical preconditions.

Ružbarský (2018) stated that the aim of the national testing is to determine the physical performance of children in Slovakia and, in addition, to bring them to sports, so that physical activity becomes part of their daily routine or. of life. This will also increase the likelihood of identifying sports-gifted children. Primary school pupils from the first grade take tests in four types of tests. First, somatic parameters (height and body weight) are determined, then the level of static and dynamic force is determined, as well as the level of endurance, speed, mobility and coordination. This diagnosis also differs from other motor tests in schools by additional, specific tests, which determine the manipulation and decision-making abilities of students, which are important especially for sports games. The goal is also supplemented by the National Sports Centre institution. It is published on their website that the project is aimed at finding out the state of movement preconditions of children at such an early age, because for the healthy development of a child and for sports performance in adulthood, comprehensive physical training and regularity of movement in childhood is decisive. Pupils' innate preconditions can be proven already in this type of testing of pupils, and thus they have the opportunity to show better results in the chosen sport, which also increases their motivation for further sports activities.

Šimonek (2018) defined the aim of regular testing of motor performance of schoolchildren as improving the selection and training of talented sports youth and finding out the status and trend of the level of physical performance of children and youth. The effectiveness of such a selection of sports talents among children in primary schools should be increased, which is also reflected in the composition and number of members in sports clubs. The described testing according to Šimonek \& Židek (2019) has not only the task of selecting sports talents from among students, but also serves for research activities that deal with the health and condition of children in Slovakia.

The aim of the work was to compare the somatic and selected movement skills of firstgrade pupils in Svit with the national research of primary schools. 


\section{Characteristics of the sample}

Testing of students was carried out in 2018 at two primary schools in Svit. 42 boys of the first grade of primary school in Svit took part in the deliberate research. First-grade teachers, gymnasts, 8th and 9th grade students and one author of the paper were involved in the testing. Students performed testing, which took place in 3 cycles. The first cycle took place at both schools in the first lesson in the classroom. It was carried out by class teachers and consisted of measurements of somatic indicators (body height and body weight). Subsequently, all students went to the school gym. In the second cycle, students were divided alphabetically into groups, where 4 stages from motor tests were created. After completing 4 motor tests, students had a half-hour break. The third cycle consisted of further motor tests. Based on a personal and written request from the management at primary schools and an explanation that it will be the use of data for research purposes, the author was allowed to use data from both schools.

\section{Methods}

The data collection consisted of measuring body height and body weight. For our research, we selected only some movement skills - sit-ups per 1 min., maximal forward bend in sitting position, standing long jump, shuttle running 4x10 m and endurance shuttle running Beep test. The given instructions were followed during the testing. Measurements were performed at primary schools on 10. 10. and 25. 10. 2018.

\section{Methods of processing and evaluation of the obtained data}

We used mathematical-statistical characteristics to process and evaluate the obtained data. From statistical methods, we used the Shapiro - Wilk test to evaluate the normality of the data, and then we calculated using a parametric unpaired t-test. In this work, we evaluate the results in percentages. In the research, we compared the performance of students measured with the results of the whole Slovakia and with the norms of the population (Sedláček \& Cihová 2009). Level in the motor test sit-ups per 1 min. we calculated according to z-points and the level in the test the maximal forward bend in sitting position was recalculated according to the made scale to the values according to Sedláček \& Cihová (2009). Based on the total sum of points from the entire test battery, we evaluated the versatile physical readiness of each tested student. Subsequently, we selected probands from the group, which we would include in specialized preparations focused primarily on athletic all-round exercise training. We 
concretized the interpretation of the resulting values using theoretical research methods (analysis, synthesis, induction and deduction).

\section{Results}

The groups of pupils from Svit $(n=42)$ and Slovakia $(n=9,443)$ compare boys who are only 6 years old according to the decimal age and the homogeneity of both groups was preserved. In Table 1 there are shown the statistical characteristics of somatic indicators of pupils for the first grades of primary schools from Svit and from the whole of Slovakia.

Table 1

Mathematical-statistical characteristics of somatic indicators of pupils of the first grade of primary schools in Svit $(n=42)$ and national testing $(n=9,443)$

\begin{tabular}{|c|c|c|c|c|c|c|}
\hline \multirow{2}{*}{ Pupils } & \multicolumn{2}{|c|}{ Body height [cm] } & \multicolumn{2}{c|}{ Body weight $[k g]$} & \multicolumn{2}{|c|}{ BMI } \\
\cline { 2 - 7 } & Svit & Slovakia & Svit & Slovakia & Svit & Slovakia \\
\hline $\mathbf{X}$ & 122,88 & 122,90 & 24,48 & 24,40 & 16,17 & 16,10 \\
\hline Xmin & 109,00 & 98,00 & 19,00 & 14,00 & 13,02 & 10,30 \\
\hline Xmax & 139,00 & 157,00 & 41,00 & 65,00 & 24,64 & 33,10 \\
\hline Vr & 30,00 & 59,00 & 22,00 & 51,00 & 11,62 & 22,80 \\
\hline Sd & 5,24 & 5,80 & 4,12 & 4,70 & 2,05 & 2,36 \\
\hline
\end{tabular}

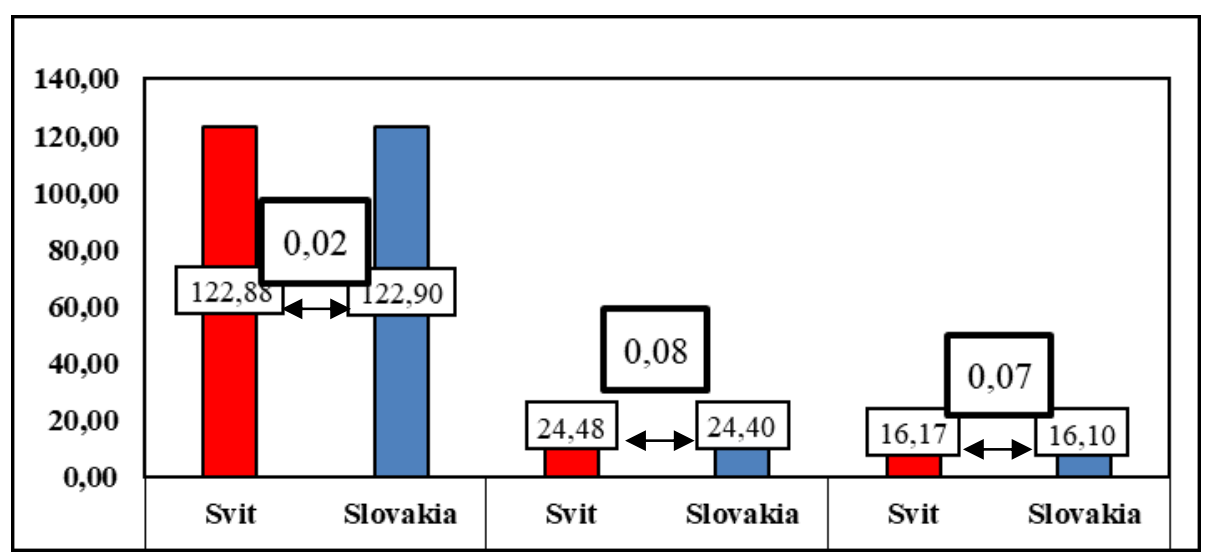

Figure 1

Comparison of physical indicators of pupils $(n=42)$ of the first grade of primary school in Svit with the national average $(n=9443)$

Based on Table 1 we see that the average values for all three monitored somatic indicators are almost identical. This is also confirmed by Figure 1, where we did not find significant differences between any monitored parameters that could affect performance in the monitored motor skills. Of course, we noticed the biggest differences in the variation ranges between students from Svit and Slovakia. In body height and body weight, the differences are 
exactly the same $29 \mathrm{~cm}$ resp. $29 \mathrm{~kg}$. This is also related to the large variation range of BMI values 11, 62, resp. 22, 80 in favour of students from Svit.

The first motor test was the maximal forward bend, which was performed in the school gym with the help of a bench and a created scale. Pupils in Slovakia achieved an average performance of $3.90 \mathrm{~cm}$. The average performance for boys in the first grade of primary school in Svit was $3.02 \mathrm{~cm}$ (Figure 2). In this comparison, we did not confirm any significant differences in performance, the differences were $22.56 \%$ in favour of students from national research. Among the students, we found individuals who achieved a performance better than 8 $\mathrm{cm}$, and thus demonstrated above-average performance compared to population standards, because they would get more than 8 points in the points evaluation (Sedláček \& Cihová 2009).

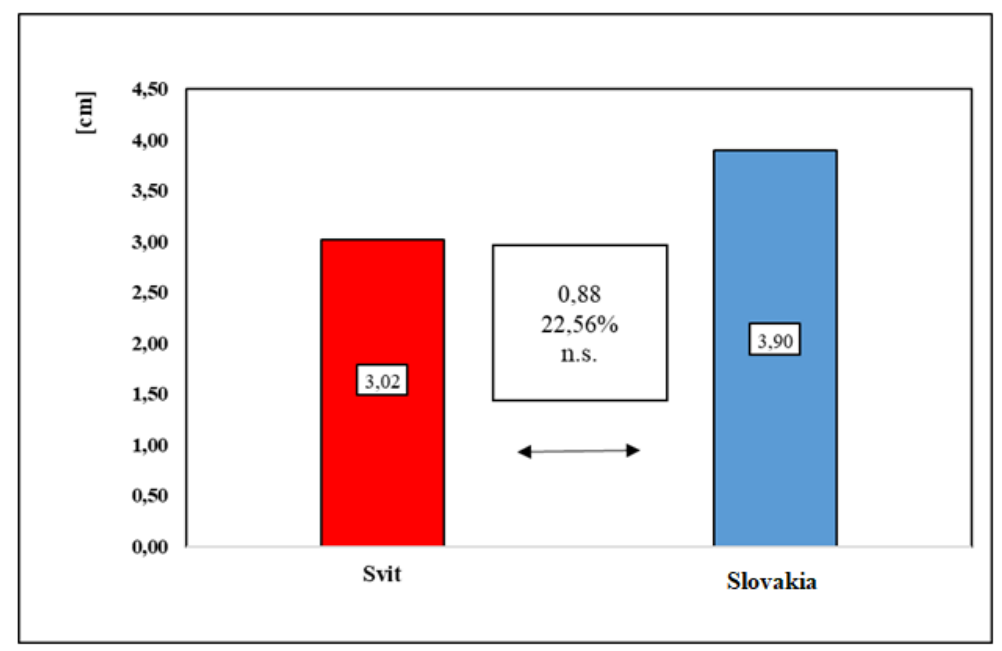

Figure 2

Comparison of the performance of pupils $(n=42)$ of the first grade of primary school in Svit with the national average $(n=9443)$ in the motor test maximal forward bend

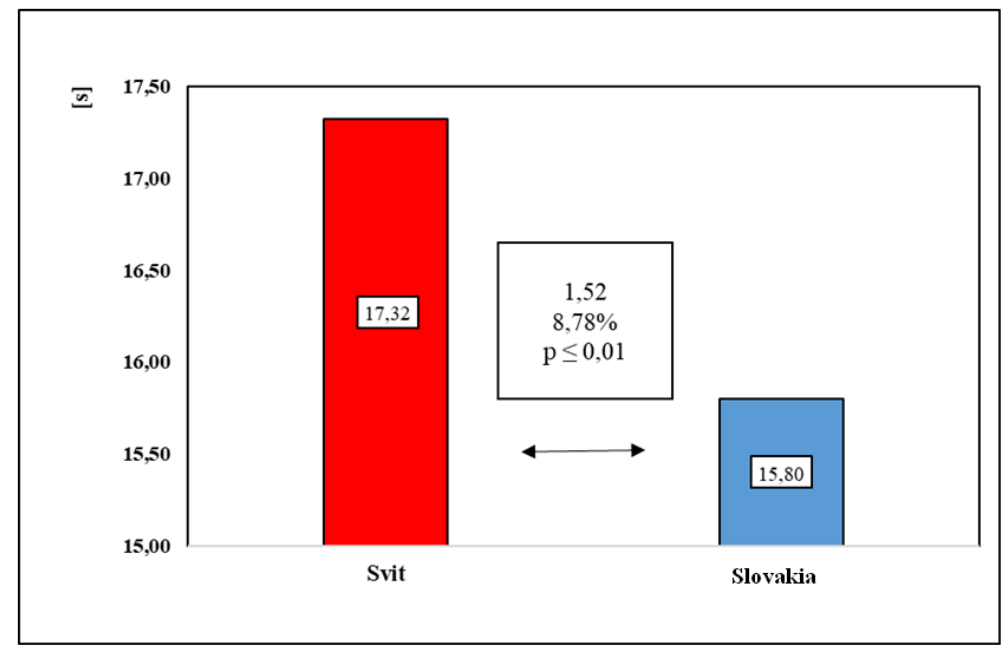

Figure 3

Comparison of the performance of pupils $(n=42)$ of the first grade of primary school in Svit with the national average $(n=9443)$ in the motor test shuttle run $4 \times 10 \mathrm{~m}$ 
In a 4 x 10 m shuttle run, pupils from Slovakia (Figure 3) achieved an average output of $15.80 \mathrm{~s}$. The group consisting of pupils from Svit reached an average time of $17.32 \mathrm{~s}$. After subtracting the values, we found a difference in time of 1.52 with (https://www.testovanieziakov.sk/content/files/NSC_NP_vysledky.pdf). This value of the difference created $8.78 \%$ of the performance of students from Svit. The difference between the groups of students was significant at the $1 \%$ level of statistical significance.

Higher homogeneity of performance was demonstrated among probands from Svit, whose standard deviation reached the value of 2.27. In contrast, the value of this degree of variability in the nationwide group of students is 3.38. This difference in values is mainly influenced by the different number of probands of individual groups, but also by extreme values. While in the group of pupils from Svit the maximum power was $24.30 \mathrm{~s}$ and the minimum power was $14.20 \mathrm{~s}$, in the group of pupils from Slovakia the values were as follows 77.00 resp. $10.10 \mathrm{~s}$.

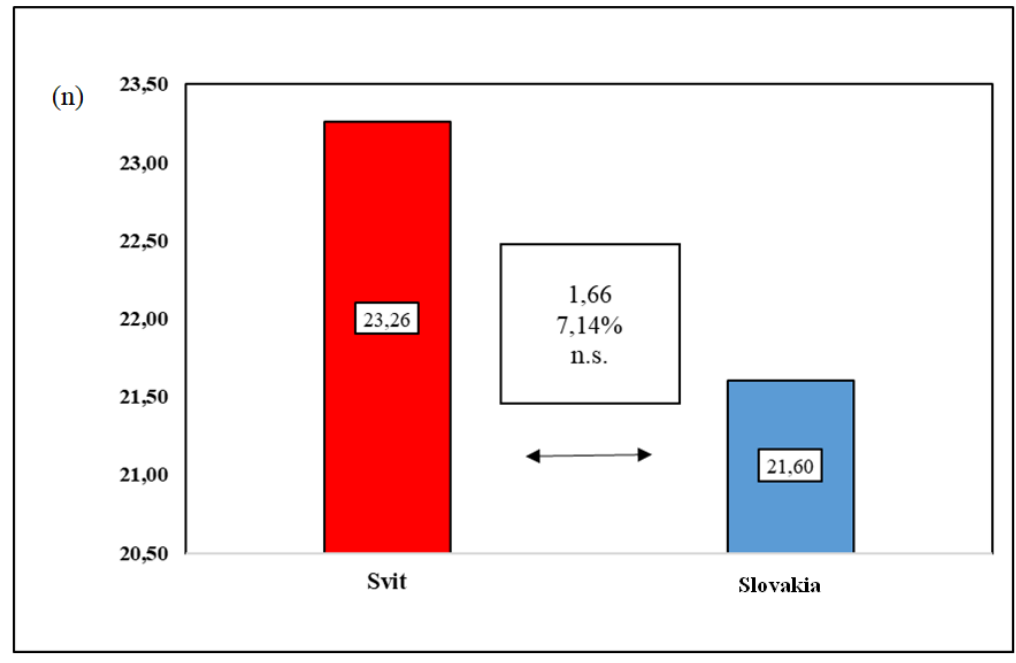

Figure 4

Comparison of the performance of pupils $(n=42)$ of the first grade of primary school in Svit with the national average $(n=9443)$ in the motor test sit-ups per 1 minute

In Figure 4 we can see that the average performance in the test of sit-ups per $1 \mathrm{~min}$. There were 21.60 repetitions of pupils in Slovakia. We recorded a better result in the group of boys from Svit, whose average value reached 23.26 repetitions. The difference between the groups was 1.66 repetitions, which is $7.14 \%$ and we did not find any significant differences between the groups. We noticed a big difference in the maximum number of repetitions. The best student in Slovakia managed to perform 77 repetitions, while the best boy from Svit only 41. Therefore, there was a big difference between the variation ranges of individual groups of 77 and 39. It follows that in Slovakia there was a 6-year-old student who did not even one repetition. We recalculated the individual performances using z-points. We did not find that we 
had a student from Svit in the group, in which we would notice above-average performance in this test. The best proband scored 2.25 points, making it one of the population averages.

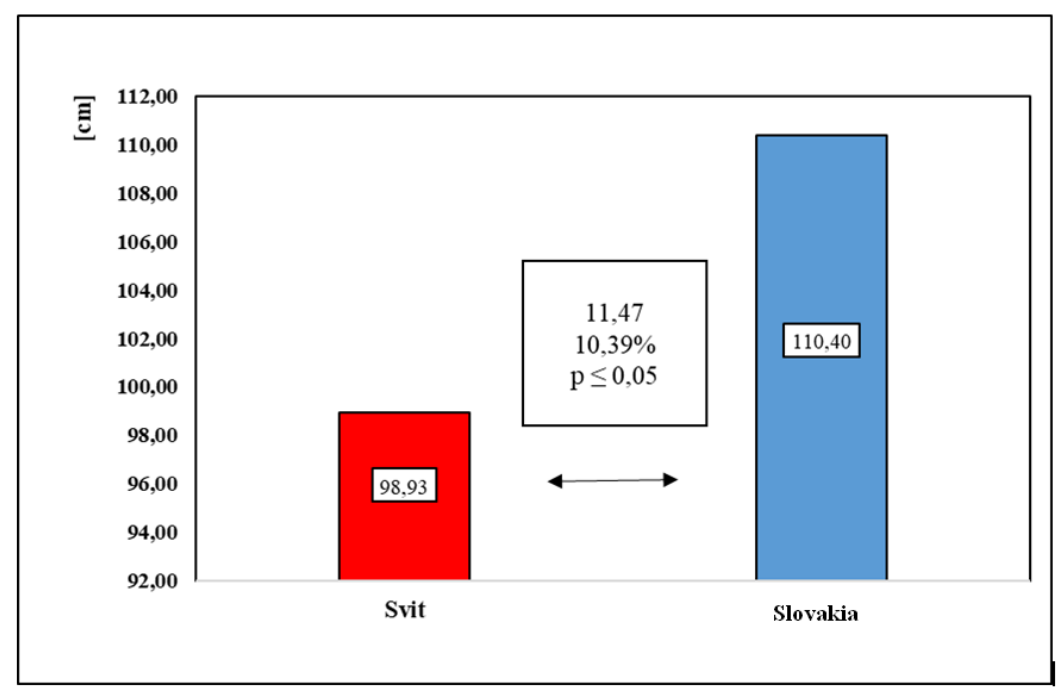

Figure 5

Comparison of the performance of pupils $(n=42)$ of the first grade of primary school in Svit with the national average $(n=9443)$ in the motor test standing long jump

The national average of pupils in this test was $110.40 \mathrm{~cm}$. An average of $98.93 \mathrm{~cm}$ was calculated within probands from Svit (Figure 5). The difference between the groups is 11.47 $\mathrm{cm}$, which makes a $10.39 \%$ difference in terms of percentages. Between students from Slovakia and Svit, we confirmed a significant difference in performance in stading long jump at the $5 \%$ level of statistical significance. The minimum and maximum values of pupils from Svit were 60 resp. $129 \mathrm{~cm}$ and national research 11 resp. $192 \mathrm{~cm}$. The higher homogeneity of the group was confirmed in the group of pupils from Svit, which was proved by the standard deviation of pupils from Svit 17.53 as a measure of the variability of the all-Slovak group $19.46 \mathrm{~cm}$.

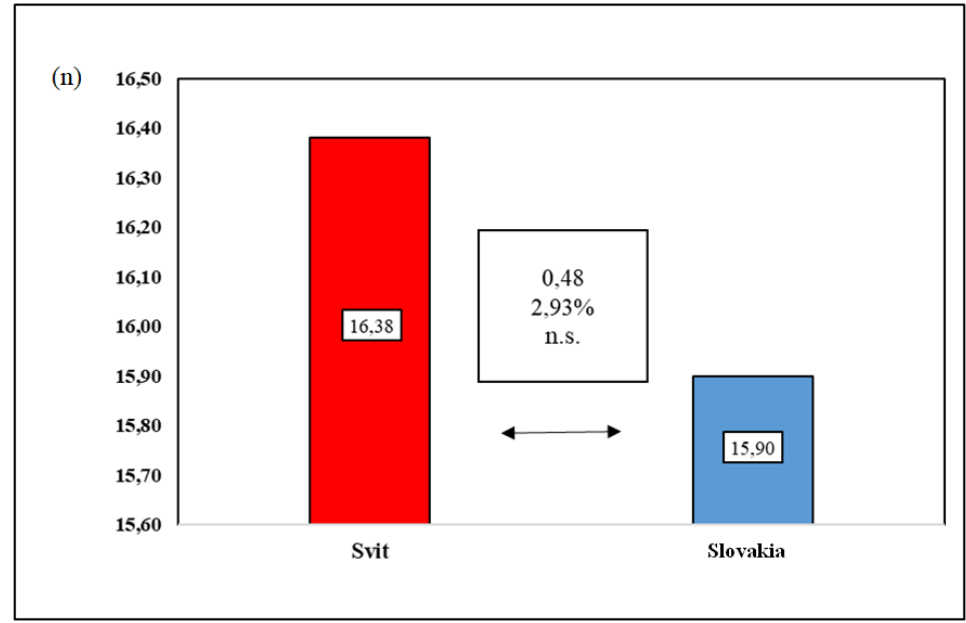

Figure 6

Comparison of the performance of pupils $(n=42)$ of the first grade of primary school in Svit with the national average $(n=9443)$ in the motor test endurance shuttle running Beep test 
In Slovakia, in the endurance shuttle running Beep test, an average of 15.90 length was run by primary school students from the first grade. This value was lower compared to the students from Svit, who managed to overcome 16.38 lengths. The difference between the groups thus climbed to 0.48 and represented $2.93 \%$, and we did not find any significant differences between the groups. There was a small difference between these rates in the extreme performance of students. The best student in Slovakia ran 40 lengths and the best proband from Svit 36 lengths. There was a small difference even at the lowest values of running lengths. There was a pupil among national research who managed to run only 1 length and the pupil ran only 3 lengths from Svit.

Another objective of our research was to find individuals who demonstrated higher allround motor readiness, but also individual above-average performance in some of the monitored test. There are many publications (Havlíček \& Kuchen 1963 - 1971; Grasgruber \& Cacek 2008; Vičan 2019) characterizing performance standards influencing the motivation and orientation of children to individual sports. To evaluate these parameters, we scored the results measured by us according to population standards (Sedláček \& Cihová 2009). The authors use a 10-point scale, where values $5-6$ represent the average level of population performance, values $7-8$ represent above-average performance and values $9-10$ represent a significant above-average population performance. For the inclusion of children in the selection of students with higher physical readiness, we set a point limit of 25 points. This lower limit of points is the average of the physical performance of the population from the five tests we monitored. We also included children according to Glesk (1989), who did not meet the standards set by us, but achieved excellent results only in some indicators that have an affinity for athletic disciplines such as level in aerobic endurance, in standing long jump and so on. From all the students, we selected 8 students for the athletic training. Of these, only 4 overcame the 25 -point scale in the range of $25-28$ points. The other 4 would gain above-average performance, ie. 7 points and more in the tests we followed in the research. However, we did not specifically evaluate the test of endurance over grasp in this paper in terms of differences in performance between students from Svit and the national survey.

\section{Conclusion}

From the results of a nationwide survey comparing our testing, several measured values are a bit incomprehensible to us. These are mainly the measured maximum values in the national survey. We are looking for an explanation in several factors. We see the first negative 
factor of such measured "incredible, extreme performances" in the fact that the testing was carried out throughout Slovakia by many examiners who had no experience and followed only written instructions. The second factor that may have influenced the results of national testing may have been the integration of children with health disorders. There could be schools that included these children in the testing and the children had problems with the implementation of individual tests. We recommend that for such disadvantaged children, either safer alternatives of motor tests be devised or children be involved in testing, but only in those tests that would not endanger the child's health. However, it should be taken into account that these children should not be included in the national average results. We would include 8 boys in the athletic training based on the standards we set.

\section{References}

1. GLESK, P., 1989. Atletická príprava detí vo veku 10 až 14 rokov. Bratislava: 1. vydanie. ISBN 80-7096-062-0.

2. GRASGRUBER, P., \& J. CACEK, 2008. Sportovní gény. Brno: Computer press. ISBN 978-80-251-1873-3.

3. HAVLÍČEK, I., \& A. KUCHEN, 1963 - 1971. Kritéria výberu detí do l'ahkoatletickej prípravy. In: Acta Facultatis educationis physicae univeritas comenianae. Bratislava: Fakulta telesnej výchovy a športu, s. 503-517. 67-556-74.

4. NÁRODNÉ ŠPORTOVÉ CENTRUM, 2019. Všeobecné informácie [online]. [cit. 2020-2403]. Dostupné z: https://www.testovanieziakov.sk/stranka/vseobecne-informacie

5. NÁRODNÉ ŠPORTOVÉ CENTRUM, 2019. Výsledky prvého celoštátneho testovania pohybových predpokladov žiakov 1. ročníkov základných škôl. [online]. 2019 [cit. 2020-2503]. Dostupné z: https://www.testovanieziakov.sk/content/files/NSC_NP_vysledky.pdf

6. NÁRODNÉ ŠPORTOVÉ CENTRUM, 2019. Geografické dáta. [online]. 2019 [cit. 202025-03]. Dostupné z: https://www.testovanieziakov.sk/statistiky/geograficke-data

7. RUŽBARSKÝ, P., 2018. Pohybová výkonnost' detí sa v porovnaní s minulost’ou výrazne zhoršila. https://zivot.pluska.sk/rozhovory/zacnu-testovat-prvakov-pohybova-vykonnostdeti-porovnani-minulostou-zhorsila)

8. SEDLÁČEK, J. \& I. CIHOVÁ, 2009. Športová metrológia. Bratislava: ICM AGENCY. ISBN 978-80-98257-15-7.

9. ŠIMONEK, J., 2018. Povinné testovanie pohybovej výkonnosti žiakov 1. ročníka ZŠ podl’a nového zákona o športe. In: Športový educator. 9(2), 3-7. 
10. ŠIMONEK, J., \& R. ŽIDEK, 2019. Talent v športe (vyhl'adávanie, identifikácia a rozvoj). Nitra: Pedagogická fakulta Univerzita Konštantína Filozofa. ISBN 978-80-558-1413-1.

11. VIČAR, M., 2018. Sportovní talent komplexní př́stup. Praha: Grada Publishing, a.s. ISBN 978-80-271-0841-1.

(https://www.testovanieziakov.sk/statistiky/somatometricke-udaje)

(https://www.testovanieziakov.sk/stranka/metodicke-pokyny-pre-testovanie) 